\title{
PENDIDIKAN SEKSUAL REMAJA MELALUI POSKESJA
}

\author{
Henni Febriawati ${ }^{1}$, Padila $^{2 *}$, \& Betri Anita ${ }^{3}$, \\ ${ }^{1,3}$ Program Studi Kesehatan Masyarakat, \\ ${ }^{2}$ Program Studi Ilmu Keperawatan, \\ Fakultas Ilmu Kesehatan Universitas Muhammadiyah Bengkulu \\ * Correponding author : padila@umb.ac.id
}

\begin{abstract}
ABSTRAK
Masa remaja adalah masa yang khusus dan penting, karena merupakan periode pematangan organ reproduksi manusia. Masa remaja disebut juga masa pubertas, merupakan masa transisi yang di tandai dengan perubahan fisik, emosi dan psikis. Remaja berada dalam situasi sangat peka terhadap pengaruh nilai baru, nilai yang datang dari luar maupun dari dalam dirinya. Masalah yang paling banyak dibicarakan remaja saat ini, seperti masalah seksualitas dan perilaku menyimpang dikalangan remaja, maraknya korban kekerasan seksual yang terselubung, seks bebas, kehamilan diluar nikah, pernikahan dini, tindakan perkosaan, abortus, dan sampai menghilangkan nyawa seseorang demi menunaikan hasyratnya. Kegiatan ini bertujuan untuk membentuk pos kesehatan remaja (POSKESJA) di SMA Muhammadiyah 4 Kota Bengkulu. Adapun tahap kegiatan yang dilaksanakan pembentukan POSKESJA tersebut adalah 1) Penyuluhan Tentang Bahaya Melakukan Seks Bebas, 2) Penyuluhan Tentang Macam-macam Penyakit Menular Seksual, 3) Penyuluhan tentang perilaku meyimpang pada remaja dan dampak-dampaknya, 4) Setiap awal dan akhir penyuluhan diberikan instrument untuk melihat pengetahuan siswa sebelum dan setelah penyuluhan, 5) Praktek P3K kepada Remaja, dan 6) Pelatihan kader, Pengukuhan struktural Poskesja dan perpustakaan mini dilengkapi referensi tentang konsep kesehatan reproduksi. Hasil dari kegiatan ini adalah terbentuknya POSKESJA di SMAM 4 Kota Bengkulu, 2) Tersusunyan pojok baca yaitu perpustakaan mini. Kehadiran POSKESJA ini di SMAM 4 ini dapat membantu remaja mengenal kesehatan reproduksi lebih dini sebagai upaya promotif dan preventif, sehingga dapat mencegah remaja terjerumus dalam pergaulan bebas dan penyimpangan perilaku kesehatan. Keberadaan POSKESJA ini telah memfasilitasi sedikitnya 30 remaja menjadi peserta.
\end{abstract}

Kata Kunci : Kaderisasi, POSKESJA, Remaja

\section{PENDAHULUAN}

Data demografi menunjukkan bahwa remaja merupakan populasi yang besar dari penduduk dunia, WHO (2010) sekitar seperlima dari penduduk dunia adalah remaja. Sekitar 900 juta berada di negara sedang berkembang. Di Indonesia menurut Biro Pusat Statistik (2010) kelompok remaja adalah sekitar $22 \%$ yang terdiri dari $50,9 \%$ remaja laki-laki dan $49,1 \%$ remaja perempuan (Bappenas, UNFPA, 2014). Hal ini tentunya dapat menjadi aset bangsa jika remaja dapat menunjukkan potensi diri yang positif namun sebaliknya akan menjadi petaka jika remaja tersebut menunjukkan perilaku yang negatif bahkan sampai terlibat dalam kenakalan remaja.

Hasil Penelitian BNN bekerja sama dengan Universitas Indonesia tahun (2013) menunjukkan bahwa : Jumlah penyalahguna narkoba oleh remaja sebesar $1,5 \%$ dari populasi atau 3,2 juta orang, terdiri dari $69 \%$ kelompok teratur pakai dan 31\% kelompok pecandu dengan proporsi laki-laki sebesar 
$79 \%$, perempuan $21 \%$, Kelompok teratur pakai terdiri dari penyalahguna ganja $71 \%$, shabu $50 \%$, ekstasi $42 \%$ dan obat penenang $22 \%$, dan Hasil Survey Demografi Kesehatan Indonesia (SDKI, 2012) menjelaskan kondisi remaja di Indonesia saat ini dapat digambarkan sebagai berikut : banyak terjadi pernikahan usia remaja, sex pra nikah dan kehamilan yang tidak dinginkan Aborsi 2,4 jt : 700-800 ribu adalah remaja. Penyebab dari kenakalan tersebut sangatlah bermacam-macam, salah satunya adalah faktor keluarga dan lingkungan (Sarwono, 2010).

Sebagian besar keluarga mendadak sulit untuk menjawab, ketika anak remajanya melontarkan pertanyaan yang tidak terduga, contohnya saja seperti 'ciuman itu apa'. Zaman global saat ini, pertanyaan-pertanyaan yang seharusnya dimanfaatkan para orangtua dalam memberikan pendidikan tentang seksualitas atau sex education dengan benar, agar anak tidak mencari jawaban dari sumber-sumber yang tidak bertanggungjawab. Menetapkan tujuan yang terpenting sekarang adalah dengan mempersiapkan anak sedini mungkin dan bertahap. Berbagai perubahan fisik dan mental terkadang menjadikan remaja lebih labil dan tingkat emosinya tidak stabil, Menurut conger, J.J Tahun (1991), sikap dan perilaku bisa konsisten apabila sikap dan perilaku yang dimaksud adalah spesifik dan ada relevansinya satu dengan yang lain.

Remaja adalah masa yang sangat penting dan spesifik, karena dimasa ini terjadi pematangan organ reproduksi manusia. Masa ini disebut juga masa pubertas, merupakan masa transisi atau peralihan yang di tandai dengan perubahan fisik, psikologis, emosi dan sosial. Remaja berada dalam situasi sangat peka terhadap pengaruh nilai baru, nilai yang datang dari luar maupun dari dalam dirinya. hal ini juga merupakan masa transisi emosional. Pada masa transisi ini akan membawa dampak pada remaja untuk mencari jati dirinya (Ali, 2004).

Motivasi dan pengetahuan memadai merupakan solusi untuk remaja belajar menjalani berperilaku baik dan tidak menyimpang, serta meningkatkan pergaulan yang positif dan juga mendapatkan pengalaman dan pemikiran yang lebih kompleks. Promosi kesehatan reproduksi pada remaja sering di konotasikan sebagai pendidikan seks, di mana sebagian besar remaja belum mengetahui dan sering menganggap tabu serta tidak layak untuk dibicarakan secara terbuka (Bataha, 2014).

Dampak dari kurangnya ilmu pengetahuan dan informasi tentang kesehatan reproduksi, banyak remaja yang mempunyai perilaku penyimpangan seksual, remaja cenderung malu untuk bertanya secara terbuka kepada orangtuanya, hal ini mengakibatkan adanya kasus penyimpangan seksual pada kalangan remaja saat ini, seperti hubungan intim yang dilakukan oleh dua remaja berlainan jenis yang terjadi di kota Bengkulu belum lama ini (Caesarina, 2009).

Dari kasus permasalahan diatas dibutuhkan peran para tenaga kesehatan yaitu dengan melakukan penyuluhan dan pelatihan tentang bahaya-bahaya melakukan hubungan seks dan perilaku menyimpang serta dampakdampaknya yang akan merugikan diri sendiri, orang lain serta lingkungan masyarakat pada umumnya.Timbulnya kenakalan remaja, bukan karena murni dari dalam diri remaja itu sendiri, tetapi mungkin kenakalan itu merupakan efek samping dari hal-hal yang tidak dapat di tanggulangi oleh remaja dalam keluarganya (Soekanto, 2014).

Masalah yang paling banyak dibicarakan remaja saat ini, seperti masalah seksualitas dan perilaku menyimpang dikalangan remaja, maraknya korban kekerasan seksual yang terselubung, seks bebas, kehamilan diluar nikah, pernikahan dini, tindakan perkosaan, abortus, dan sampai menghilangkan nyawa seseorang demi menunaikan hasyratnya. Kegiatan ini bertujuan untuk membentuk pos kesehatan 
remaja (POSKESJA) di SMA Muhammadiyah 4 kota Bengkulu.

Permasalahan yang akan diangkat ialah menjelaskan kembali kepada remaja tentang bahaya-bahaya melakukan hubungan seks dan perilaku menyimpang serta dampak-dampaknya yang akan merugikan diri sendiri, orang lain serta lingkungan masyarakat pada umumnya. Masyarakat pada umumnya dirugikan dengan adanya perilaku serta dampakdampak penyimpangan seksual, remaja yang sekolah di SMA 4 Muhammadiyah kota Bengkulu berasal dari berbagai desa dan kota lain sehingga bermacam-macam karakteristik. Supaya remaja tidak terjerumus kedalam hal yang negatif, perlu adanya sosialisasi dan pelatihan untuk mengetahui bahaya seksual, serta perilaku menyimpang pada remaja dan macammacam penyakit menular seksual, oleh karena itu perlu dibentuk suatu kelompok remaja yang terlatih yang berkegiatan positif.

POSKESJA merupakan organisasi yang menjadi solusi untuk remaja di SMA Muhammadiyah 4 kota Bengkulu sendiri, sebagai wadah hearing bagi sesama remaja dalam menghadapi bukan hanya masalah sekolah juga masalah yang sifatnya pribadi, serta menjadi sarana dan prasarana pendukung dalam berorganisasi.

POSKESJA ini dikelola para anakanak yang sekolah di SMA tersebut. Diharapkan pula dapat menjadikan pusat kesehatan remaja dan pengetahuan yang sesungguhnya, akan tetapi yang lebih penting dari kegiatan ini adalah dapat memanamkan sikap atau perilaku baik serta perilaku hidup bersih dan sehat juga bagi para remaja serta tahu betul pentingnya pendidikan seksual dan pengetahuan tentang perilaku menyimpang yang sekarang marak terjadi dimana-mana.

Hidup bersih dan sehat tidak harus dengan sarana dan prasarana yang modern. Akan tetapi hidup bersih dan sehat bisa diperoleh dengan cara menjaga dan merawat apa yang ada dengan sebaikbaiknya. Keterbatasan sarana dan prasarana yang ada bisa dimanfaatkan secara optimal untuk menciptakan suatu kondisi yang bersih dan sehat. Dengan bimbingan dan pelatihan tentang bagaimana hidup bersih dan sehat, sehingga para remaja dapat mempraktekkan dalam kehidupannya serta dengan adanya suasana yang aman, damai, sejuk, indah, dan bersih dapat tercipta lingkungan yang kondusif dalam memahami buku-bacaan seputar kesehatan reproduksi di perpustakaan dengan baik.

Pengabdian masyarakat ini melibatkan seluruh siswa yang ada di SMA 4 Muhammadiyah kota Bengkulu yang terdaftar kecuali anak kelas XII yang akan menghadapi ujian nasional. Sebagian besar karakteristik anak di SMA 4 Muhammadiyah kota Bengkulu adalah berjenis kelamin laki-laki dan perempuan, ada juga yang bekerja untuk membantu ekonomi orangtua sehari-hari, dan penjaga sekolah. Bermacam-pula karakteristik dari kegiatan sehari-hari ada yang suka bermain bersama anak perempuan saja pun sebaliknya dan ada juga yang bermain bersama lawan jenisnya, kumpul-kumpul sekedarnya serta adapula yang suka mengikuti kegiatan sekolah seperti drumband. Sedangkan informasi tentang kespro di peroleh dari kawan sebaya dan internet. (Hasil Survei TIM Pemas, 2016).

SDKI (2012), berdasarkan penelitian terhadap perempuan berusia 12-24 tahun yang sudah menstruasi ternyata mereka (54\%) lebih terbuka berkomunikasi dengan teman sekolah tentang menstruasi pertama yang dialami dan $41 \%$ berbagi dengan ibunya. Sedangkan pada lelaki pengalaman mimpi basah dan perubahan fisik yang terjadi di masa pubertas hampir sebagian (48\%) membicarakannya dengan teman, dan bukan dengan ayah, ibu ataupun gurunya. Begitu juga hasil penelitian dari PP'Aisyiyah (2012) mencatat bahwa para remaja meyakini pada mitos-mitos kespro, terutama soal haid, penyebab hamil, dan caracara pencegahan kehamilan. 
POSKESJA ini, merupakan pusat yang digunakan para anak, sebagai media pembelajaran dan praktek bagaimana menangani masalah kesehatan, sebagai media untuk mengaplikasikan ilmu dan belajar dari lingkungan sekitarnya. Materi yang diberikan antara lain penyuluhan tentang bahaya-bahaya melakukan hubungan seks dan perilaku menyimpang, serta dampak-dampaknya yang akan merugikan diri sendiri, orang lain serta lingkungan masyarakat pada umumnya, perilaku hidup bersih dan sehat dan pelatihan kader POSKESJA.

\section{METODE KEGIATAN}

Kegiatan ini dilaksanakan di SMAM 4 Kota Bengkulu selama kurang lebih Dua bulan dan setiap minggu satu kali pertemuan dihari jum'at dari jam 07.3011.30 WIB dengan total jam secara keseluruhan 36 jam.

Metode pelaksanaan dari kegiatan ini adalah dengan memberikan penyuluhan, terlebih dahulu akan disebarkan instrument pretest kepada para anak di SMA 4 Muhammadiyah kota Bengkulu untuk mengetahui pemahaman sebelum penkes. Setelahnya baru Penyuluhan difokuskan kepada anak yang tergabung dalam Organisasi siswa kelas X dan XI.

Proses pelaksanaa Tim Pemas akan memberikan beberapa materi antara lain tentang bahaya melakukan hubungan seksual seperti, macam-macam penyakit menular seksual, perilaku menyimpang dan dampak-dampak negatif yang akan terjadi pada remaja. Setelah semua materi diberikan, para remaja diajak praktek diruang TRIAS P3K dan diberikan pelatihan P3K serta kegiatan lainnya yang bermanfaat. Setelah penyuluhan siswa/i diberikan lagi instrument untuk melihat ketercapaian belajar dari hasil penkes yang sudah diberikan. Instrument yang digunakan dalam pemas ini didapatkan dari sitasi beberapa artikel dan dianalisis serta didesiminasikan oleh tim pemas terkait konsep yang pas dan yang diperlukan yang kita gunakan.

Para remaja juga memperoleh bimbingan pengajaran bagaimana cara berinteraksi sosial secara baik, sesuai nilai dan norma serta adat istiadat setempat, dari itu diharapkan kedepannya remaja dapat menerapkan ilmu dan pengajaran dari kegiatan yang diperoleh didalam kehidupan sosial bermasyarakat. Kegiatan terakhir adalah membuat POSKESJA, didalamnya ada beberapa buku penunjang bacaan, lembar balik, leaflet dan poster dengan tujuan dapat memfasilitasi para remaja untuk mendapatkan pelayanan informasi kesehatan dan mendapatkan ilmu yang bermanfaat, dilengkapi dengan sarana prasarana seperti tensi, stetoskop, pengukur tinggi badan, timbangan dan obat-obatan untuk pertolongan awal.

Menurut Depkes RI (2006), posyandu adalah wadah pemeliharaan kesehatan yang dilakukan dari, oleh dan untuk masyarakat yang dibimbing petugas kesehatan terkait. Posyandu yang sudah dilaksanakan di masyarakat selama ini adalah Balita dan lansia. Program yang di usulkan dalam pemas ini adalah mengkolaborasikan program dinas kesehatan dengan program BKKBN yaitu melalui pembentukan pos kesehatan remaja (POSKESJA) dengan memasukkan materimateri PIK-KRR.

Dalam mewujudkan hal tersebut, pertama adalah membentuk peningkatan konsep karakter kesehatan bagi mahasiwa seperti 1) Penyuluhan Tentang Bahaya Melakukan Seks, 2) Penyuluhan Tentang Macam-macam Penyakit Menular Seksual, 3) Penyuluhan tentang perilaku meyimpang pada remaja dan dampak-dampaknya, 4) Praktek pertolongan pertama pada kecelakaan (P3K) kepada Remaja seperti perawatan luka sederhana, cara menolong korban kecelakaan, cara mengukur tensi darah, menimbang berat badan dan tinggi badan, 5) Pelatihan kader, Pengukuhan struktural Poskesja dan 
perpustakaan mini dilengkapi referensi tentang konsep kesehatan reproduksi.

\section{HASIL DAN PEMBAHASAN}

a) Hasil dari Penyuluhan Tentang konsep kesehatan reproduksi remaja dan bahaya Melakukan Seks Bebas

Diminggu pertama kegiatan tanggal 13 mei 2016, sebelum dilaksanakanya penyuluhan tim menyebarkan instrument untuk melihat pengetahuan peserta pemas, hasil yang didapatkan dari 30 siswa sebelum penyuluhan Tentang konsep kesehatan reproduksi remaja dan bahaya Melakukan Seks Bebas nilainya $40 \%$ menjawab mengerti kesehatan reproduksi remaja dan bahaya melakukan Seks Bebas, lalu setelah dilakukan penyuluhan, sesi tanya jawab barulah dilaksanakan postest dengan nilai rerata setelahnya adalah $65 \%$ sehingga disimpulkan terjadinya peningkatan pengetahuan yang signifikan antara sebelum dan setelah penyuluhan.

Berikut adalah dokumentasi foto kegiatan pretest sebelum penkes diberikan :

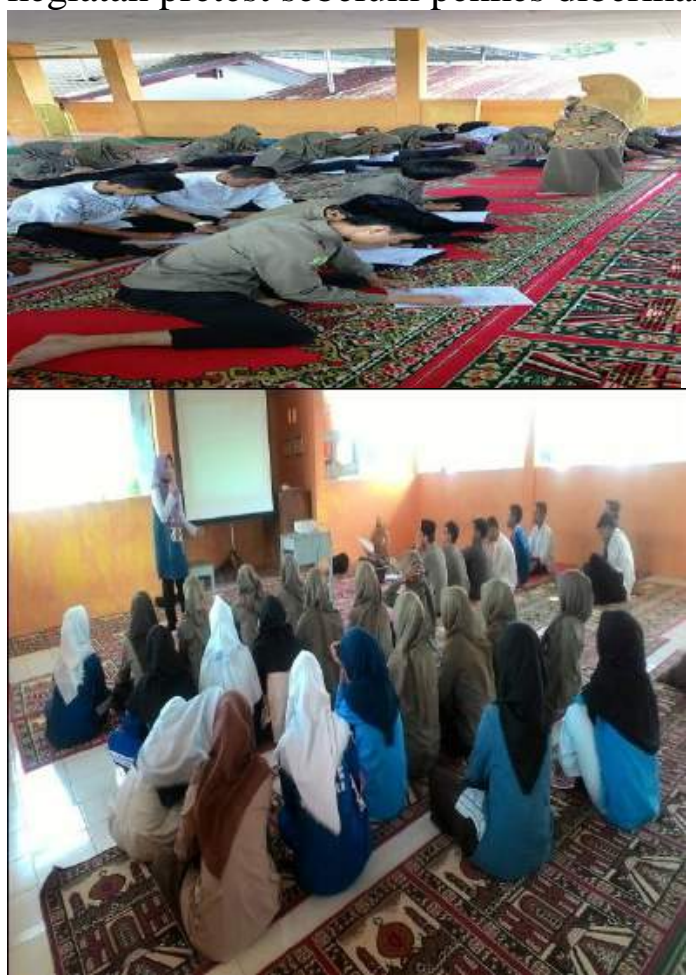

Diatas adalah proses kegiatan penyuluhan konsep kesehatan reproduksi remaja dan bahaya Melakukan Seks Bebas.

b) Hasil Penyuluhan Tentang Macammacam Penyakit Menular Seksual

Diminggu ke dua tanggal 20 mei kegiatan pemas ini, sebelum memulai penyuluhan, tim melakukan apersepsi kepada siswa terkait konsep penyakit menular seksual (PMS) yang mereka ketahui, dari 3 siswa yang ditanyakan, ke 4 siswa tersebut menjawab ragu dan belum tau apa itu PMS, dan malah ada yang menjawab PMS adalah premenstruasi. selanjutnya baru kegiatan pemberian materi dan setelahnya dilakukan postest hasilnya adalah $70 \%$ dari 30 siswa mengerti tentang konsep penyakit menular seksual.

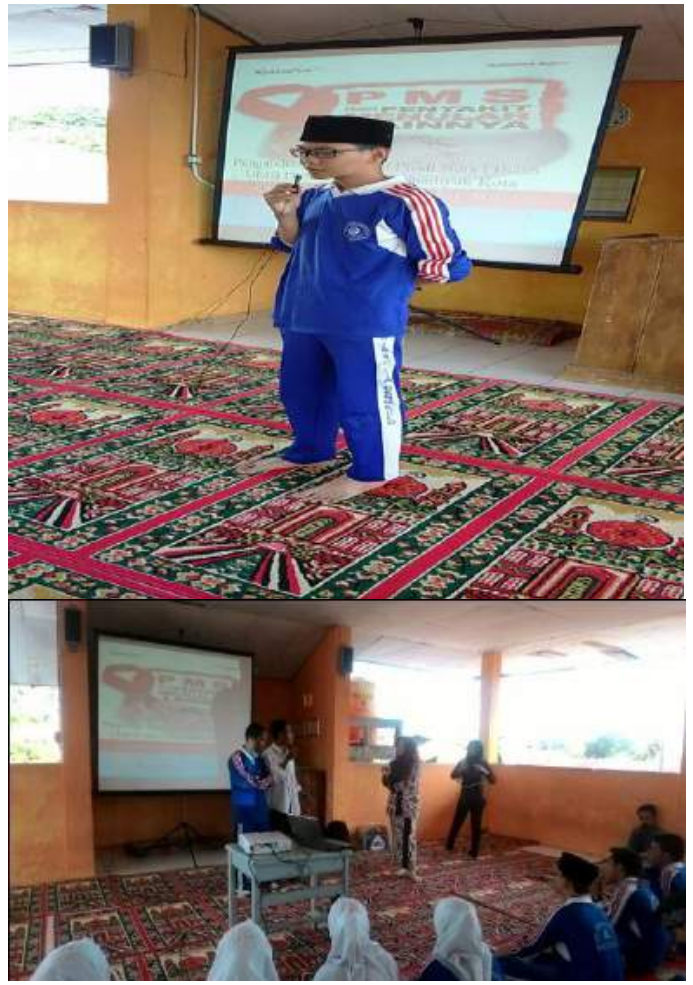

Dokumentasi kegiatan apersepsi konsep PMS. 


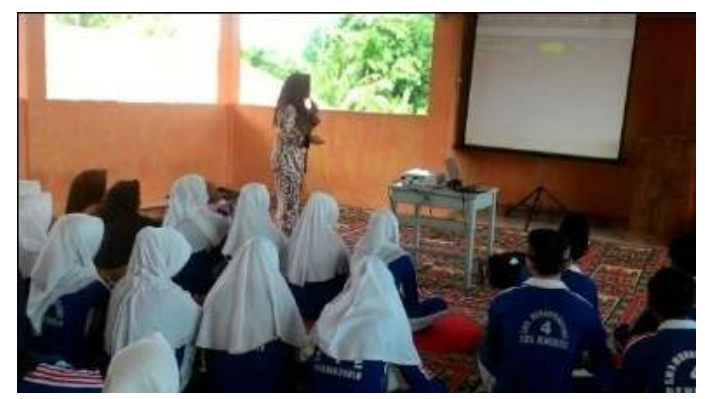

Dokumentasi kegiatan pen.kes

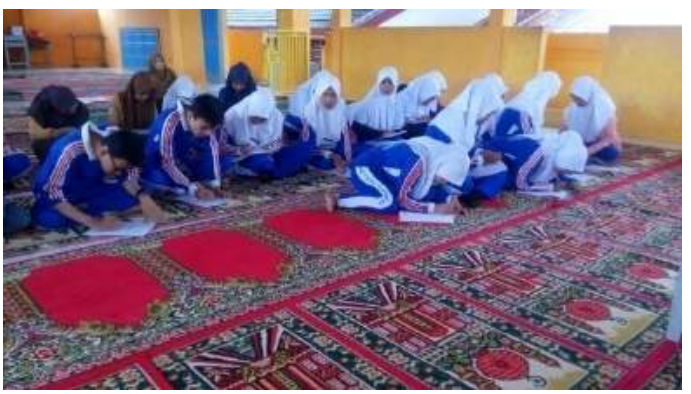

Dokumentasi Postest setelah penkes

c) Hasil Penyuluhan tentang perilaku meyimpang pada remaja dan dampakdampaknya

Diminggu ke tiga 27 mei 2016 kegiatan pemas ini, sebelum memulai penyuluhan, tim melakukan apersepsi kepada siswa terkait konsep perilaku menyimpang remaja dan dampaknya yang mereka ketahui, dari 5 siswa yang ditanyakan, ke 5 siswa tersebut menjawab belum jelas apa saja kategori perilaku menyimpang pada remaja, Selanjutnya baru kegiatan pemberian materi dan setelahnya dilakukan postest hasilnya adalah $72 \%$ dari 30 siswa mengerti tentang konsep penyakit menular seksual.

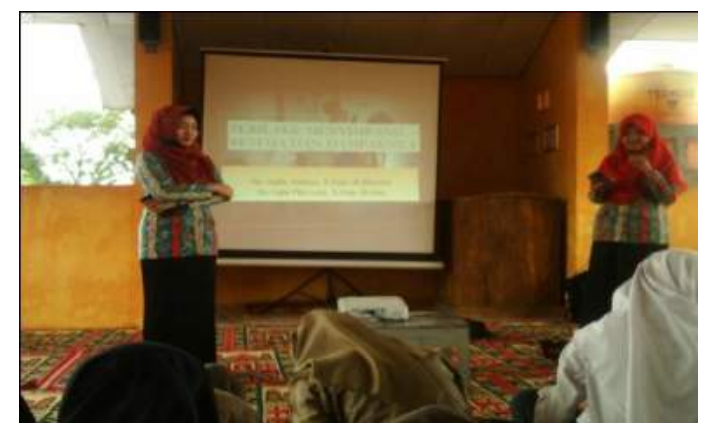

Dokumentasi proses apersepsi terhadap materi yang akan disampaikan

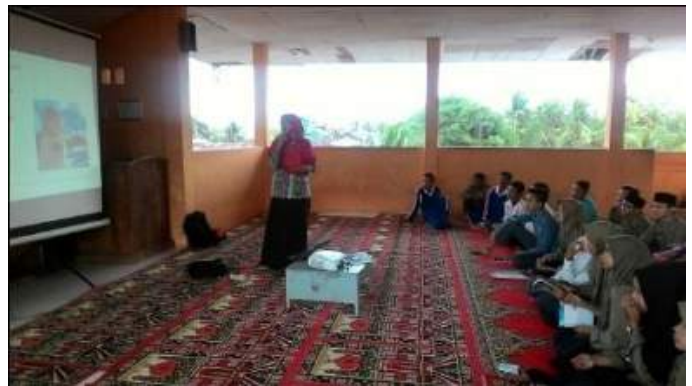

Dokumentasi kegiatan penkes

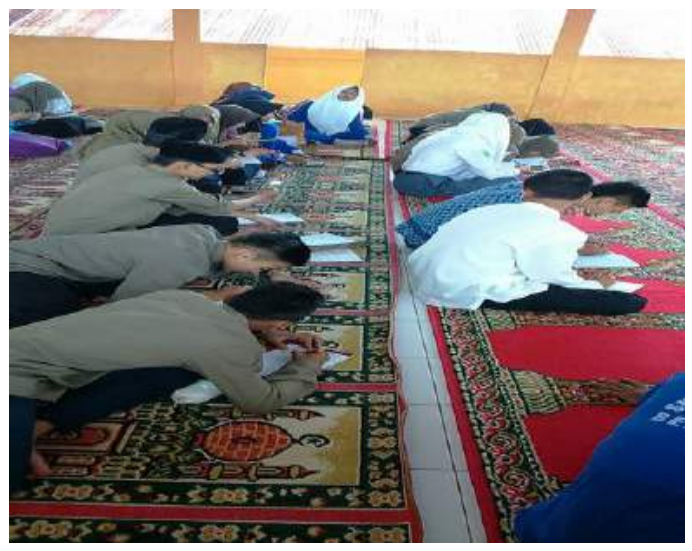

Dokumentasi kegiatan postest setelah materi diberikan

\section{d) Hasil Praktek P3K kepada Remaja}

Diminggu ke empat 3 juni 2016 kegiatan pemas ini, sebelum memulai penyuluhan, tim melakukan apersepsi kepada siswa terkait konsep pos kesehatan remaja yang mereka ketahui, dari 3 siswa yang ditanyakan, ke 3 siswa tersebut menjawab sudah jelas apa saja kegiatan yang dilaksanakan pada POSKESJA ini, Selanjutnya baru kegiatan pemberian materi dan setelahnya dilakukan postest hasilnya adalah $85 \%$ dari 30 siswa mengerti tentang konsep POSKESJA. 


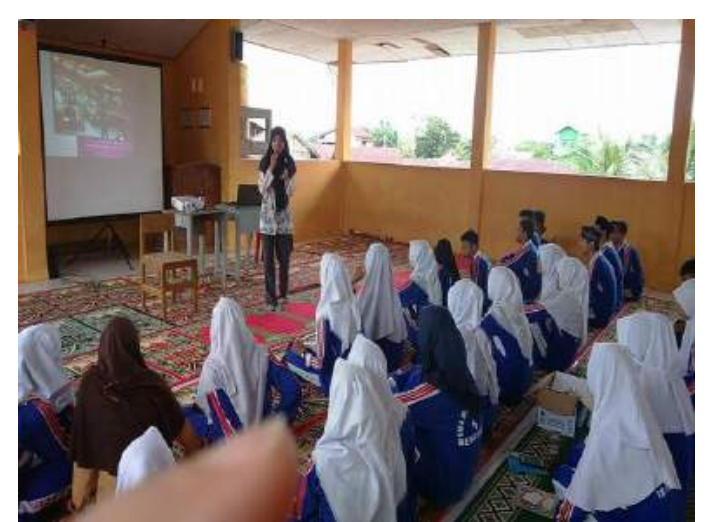

Dokumentasi pemberian materi pos kesehatan remaja

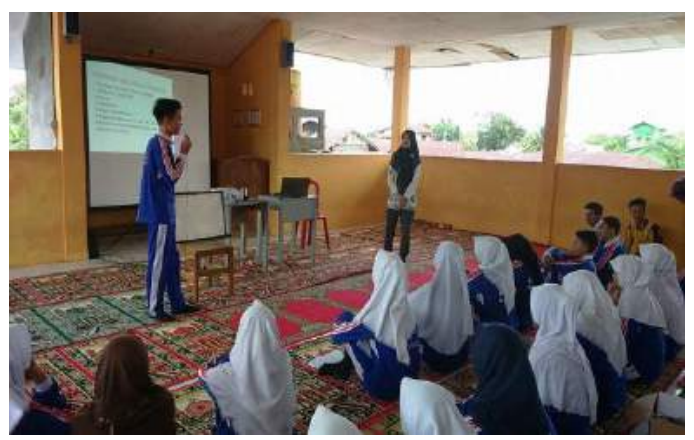

Dokumentasi proses tanya jawab

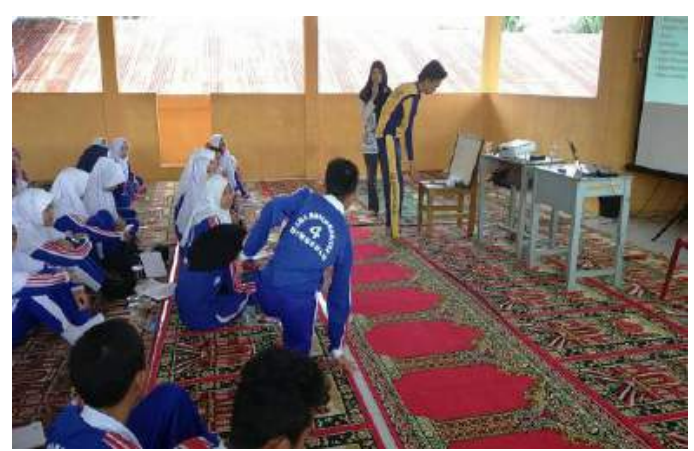

Dokumentasi pemilihan ketua poskesja oleh siswa

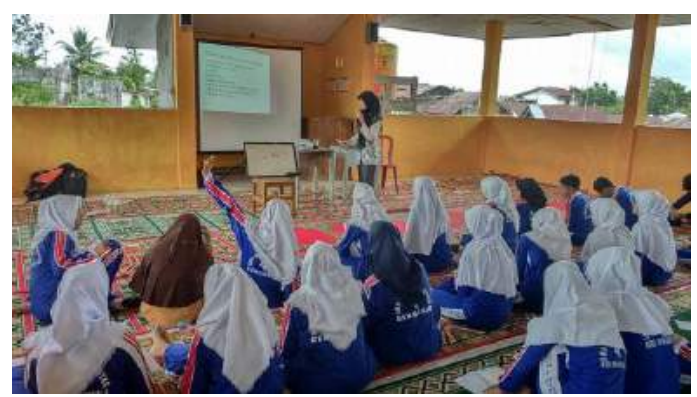

Dokumentasi pembacaan hasil pemilihan struktur POSKESJA e) Hasil Pelatihan kader, Pengukuhan struktural Poskesja dan perpustakaan mini dilengkapi referensi tentang konsep kesehatan reproduksi.

Diawali dengan pemberian konsep P3K, selanjutnya sesi tanya jawab dan terakhir adalah praktek langsung terkait bagaimana pertolongan pertama pada kecelakaan, cara perawatan luka sederhana, cara membersihkan dan membalut luka, praktek cara mengukur tekanan darah, Tinggi badan, berat badan, dan memberikan bimbingan konseling ketika ada teman yang mengajak hearing. Berikut adalah dokumentasi kegiatannya :

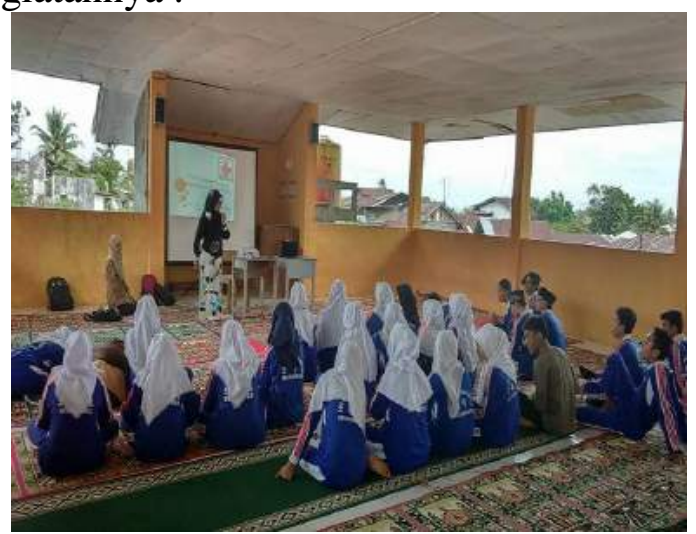

Dokumentasi kegitan penkes P3K

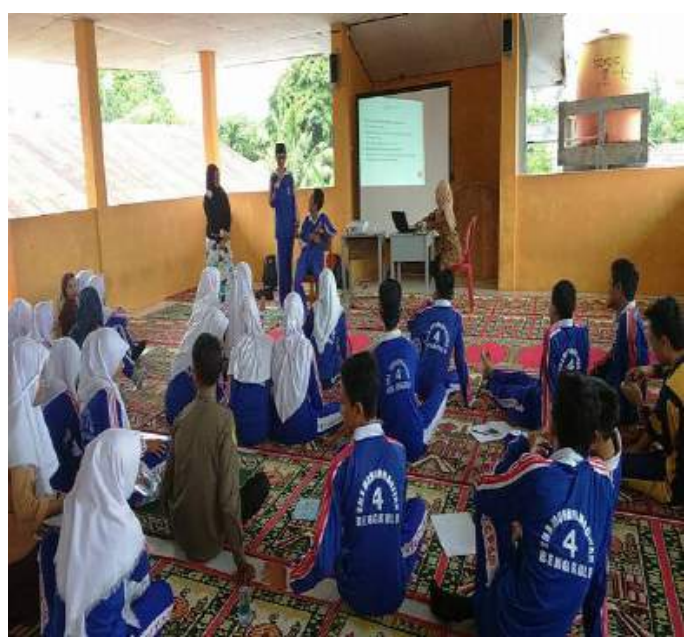

Dokumentasi kegiatan praktek P3K minggu ke 5, 10 juni 2016 


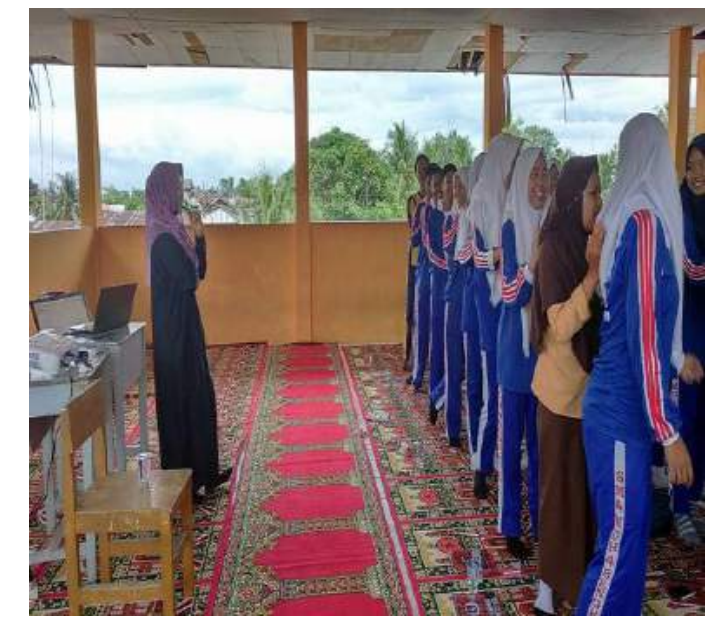

Dokumentasi kegiatan praktek P3K Minggu ke enam, 17 juni 2016

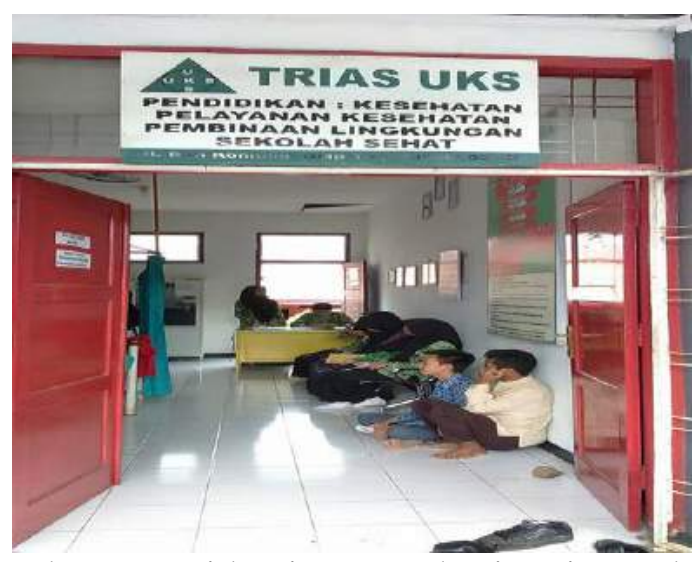

Dokumentasi kegiatan poskesja minggu ke tujuh di UKS, 24 juni 2016

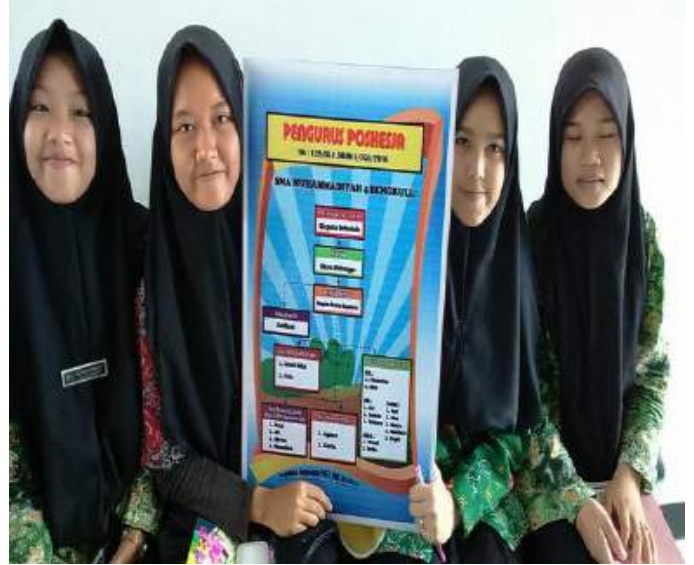

Dokumentasi Pengurus Poskesja SMAM 4 Muhammadiyah Bengkulu dan telah di SK kan oleh Kepala sekolah

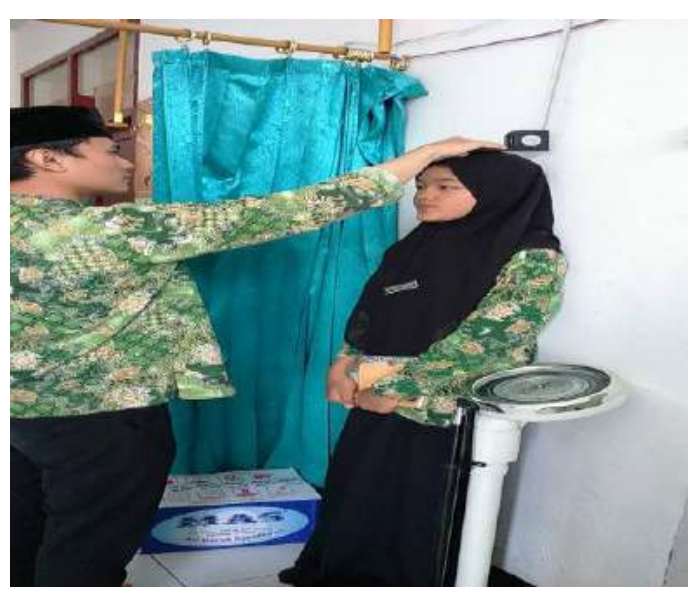

Dokumentasi Kegiatan pengukuran TB dan BB

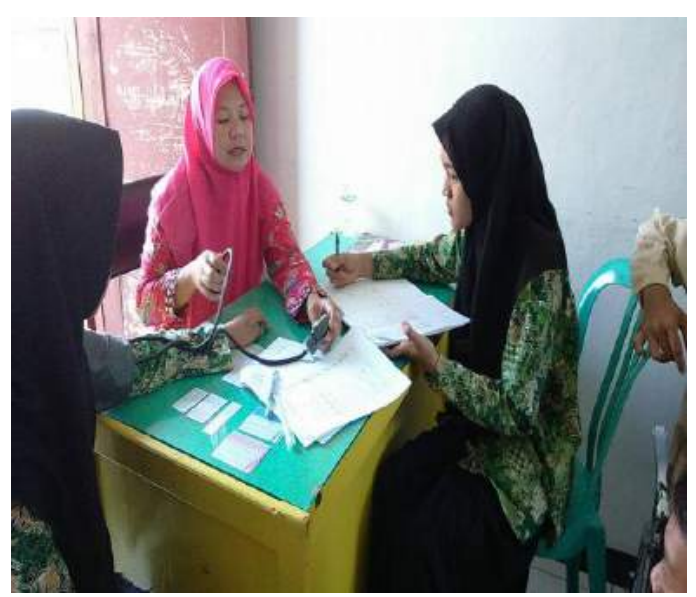

Dokumentasi kegiatan pelatihan Pengukuran Tensi darah dan Pencatatan hasil dengan melibatkan perawat puskesmas Sukamerindu

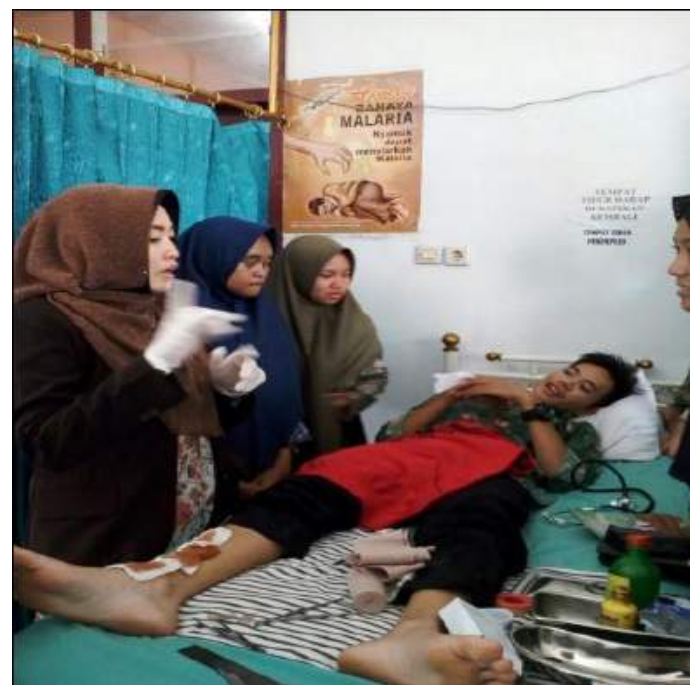

Dokumentasi kegiatan praktek Perawatan luka 


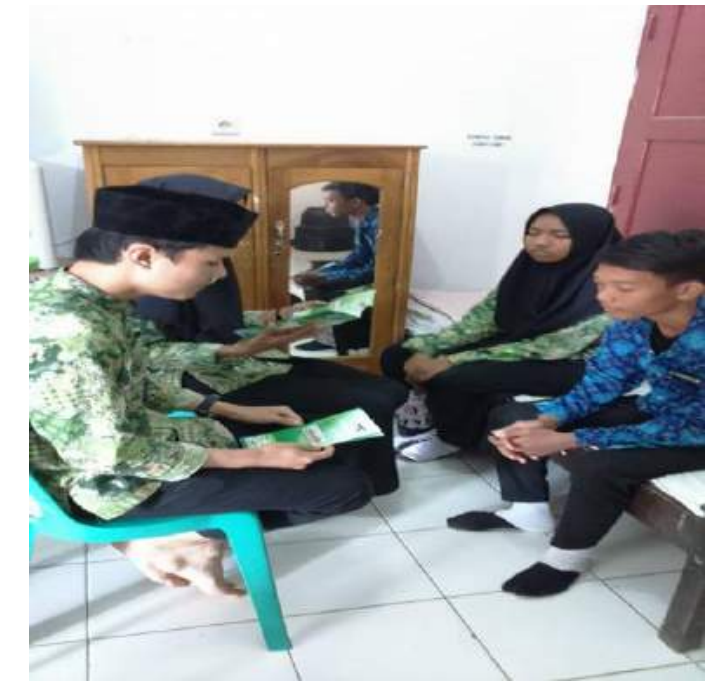

Dokumentasi Kegiatan Konseling di ruang BK oleh Anggota POSKESJA

\section{PENUTUP}

\section{Kesimpulan}

Hasil dari pemas ini adalah

1. Terbentuknya POSKESJA di SMAM 4 Kota Bengkulu

2. Peningkatan pengetahuan siswa setelah diberikan penkes reproduksi remaja dan bahaya Melakukan Seks Bebas $65 \%$ dari $40 \%$ sebelum pemberian materi

3. Peningkatan pengetahuan siswa setelah diberikan penkes Tentang Macammacam Penyakit Menular Seksual $70 \%$ dari $30 \%$ sebelum pemberian materi

4. Peningkatan pengetahuan siswa setelah diberikan penkes perilaku meyimpang pada remaja dan dampak-dampaknya 72 $\%$ paham konse setelah diberikan materi

5. Peningkatan pengetahuan siswa setelah diberikan materi dan praktek P3K dan ruang lingkup Poskesja $85 \%$ mengerti konsep setelah diberikan materi

6. Terpublikasinya hasil pengabdian masyarakat ini di jurnal yang dikelola LPPM UMB,

7. Sebagai bahan pengayaan untuk penyusunan buku ajar pada asuhan keperawatan komunitas,

8. Kehadiran Poskesja ini di SMAM 4 ini dapat membantu remaja mengenal kesehatan reproduksi lebih dini sebagai upaya promotif, preventif, sehingga dapat mencegah remaja terjerumus dalam pergaulan bebas dan penyimpangan perilaku kesehatan.

9. Keberadaan Poskesja ini telah memfasilitasi sedikitnya 30 remaja menjadi peserta Poskesja.

\section{Saran}

Kepada pihak sekolah untuk terus memotivasi dan mensupport siswa/i yang telah tergabung di unit poskesja, sehingga salah satu tujuan dari pengmas ini dapat tercapai yaitu mencegah perilaku yang negatif siswa seperti tawuran antar pelajar, mengisi kekosongan waktu dengan hal-hal yang positif seperti ikut organisasi pos kesehatan remaja serta dapat menshearkan pengetahuan yang telah dibekali oleh TIM Pemas kepada siswa lainnya sehingga SMAM 4 Bebas dan Terhindar dari perilaku yang menyimpang pada SISWA/I di sekolah Tersebut.

\section{DAFTAR PUSTAKA}

Ali, M dan Asrori, M. (2004). Psikologi remaja. Jakarta : Bumi Aksara.

Bataha, Y. 2014. Hubungan Pengetahuan dengan Sikap Remaja Tentang Perilaku Seksual Pranikah Pada Siswi Kelas X di SMA Negeri 1 Manado Tahun 2014 tersedia dalam http:ejournal.unsrat.ac.id (diakses tanggal 5 Maret 2016)

Conger, J.J. (1991). Adolescence and youth : Psikological development and changing World: Harper Collins Publiser. Newyork.

Caesarina Ancah. 2009. Kespro Remaja, disampaikan pada Seminar Nasional Seksualitas dan Kesehatan Reproduksi Remaja di PP. Nuris. Juni 2009. Jember-Jawa Timur.

Departemen kesehatan RI. 2006 Buku Kader Posyandu Dalam Usaha Perbaikan Gizi Keluarga. Jakarta. Departemen Kesehatan RI. 
Eriyani Linda Dwi. Kesehatan Reproduksi Remaja: Menyoal Solusi. 2006, disampaikan pada Seminar Nasional Seksualitas dan Kesehatan Reproduksi Remaja di PP. Nuris, Juni 2009. Jember-Jawa Timur

Herold, J.M., Monterosso, E., Morris, L., Castellanos, G., Conde, A., \& Spitz, A. 1988. Sexual Experience and Contraceptive Use among Young Adults in Guatemala City. International Family Planning Perspective.14,142-146.

Morris, L. 1988. Young Adults in Latin America and Carribean: Their Experiences and Contraceptive Use. International Family Planning Perspective. 14, 153-158.

Pinem, Saroha. 2009. Kesehatan Reproduksi dan Kontrasepsi. Jakarta : Trans Info Media,.

chnrl.org/pelatihan-demografi/SDKI2012/12 Maret 2016

www.bappenas.go.id//Proyeksi_Penduduk_ Indonesia_2010-2035./12 Maret 2016 